\title{
WORLD RED CROSS DAY
}

8 May 1970 will be celebrated throughout the world as "World Red Cross Day". The theme chosen for this event was one of the main subjects dealt with at the International Conference of the Red Cross, i.e. the development, application and dissemination of humanitarian law.

Under the aphorism

$$
\text { PROTECT MAN : THWART WAR, }
$$

the National Red Cross, Red Crescent and Red Lion and Sun Societies of more than one hundred countries will expound on this fundamental aspect of our movement's activities.

In agreement with the League, the International Committee has undertaken to co-ordinate events which will take place in various parts of the world on that occasion. Detailed documentary material on this subject will shortly be sent to all National Societies.

In particular, the ICRC plans to offer National Societies television and radio programmes in several languages, a symbolic design which may be used for posters, labels, emblems etc., articles for submission to the press, photographs, a bibliography on humanitarian law, colour slides, etc.

Preparation of this copious material has already begun. We would add that a meeting of Swiss radio and television representatives convened by the ICRC took place at the beginning of December. 